\title{
HIGH DOSE-RATE BRACHYTHERAPY AS A TREATMENT OPTION IN PRIMARY TRACHEAL TUMORS
}

\author{
Heloisa de Andrade Carvalho', Viviane Figueiredo², Wilson Leite Pedreira Jr. ${ }^{2}$, \\ and Salim Aisen ${ }^{1}$
}

Carvalho H de A, Figueiredo V, Pedreira Jr. WL, Aisen S. High dose-rate brachytherapy as a treatment option in primary tracheal tumors. Clinics. 2005;60(4):299-304.

PURPOSE: To present experience with high dose-rate endobronchial brachytherapy in the treatment of primary tracheal tumors.

PATIENTS AND METHODS: Four patients with nonresected primary tracheal tumors are presented: 2 cases of squamous cell carcinoma of the trachea, 1 of recurrent adenoid cystic carcinoma, and 1 with recurrent plasmacytoma. All received brachytherapy, alone or as a boost for primary irradiation, in 3 or 4 fractions of $7.5 \mathrm{~Gy}$, calculated at a depth of $1 \mathrm{~cm}$. Followup was considered to start from the end of brachytherapy.

RESULTS: Local control was achieved in all cases at the time of first bronchoscopic evaluation. Two patients with squamous cell carcinoma died at $6^{\text {th }}$ and $33^{\text {rd }}$ months after brachytherapy, respectively. The first had no evidence of disease, and the latter had local recurrence. The other 2 patients were alive after 64 and 110 months of follow-up, respectively, both with no evidence of disease. Tracheal stenosis developed in these 2 cases, 22 and 69 months after brachytherapy. Tracheal stent placement was needed only for the patient with an adenoid cystic carcinoma.

CONCLUSIONS: Endobronchial high dose-rate brachytherapy may be used for tracheal tumors, even as a boost for external beam irradiation, or in recurrences. Local control in 3 out of 4 patients indicates that individual cases may benefit from the treatment. Long-term survival may also be expected, mainly for tumors with adenoid cystic histology.

KEYWORDS: Radiotherapy. Brachytherapy. Tracheal tumors. High dose-rate. Complications.

Brachytherapy is the radiation treatment in which the radioactive material is located in contact with or inside the target lesion. Special applicators, needles, and catheters are used as guides for positioning the radioactive material in the patient. Endobronchial brachytherapy is performed through bronchoscopy, with the placement of one or more catheters in the lower airways. Brachytherapy has been widely used, especially after the development of high doserate (HDR) remote afterloading machines. In 1991, our group first introduced this method in Latin America. ${ }^{1}$ The advan-

Division of Oncology, Radiotherapy (InRad) ${ }^{1}$, Hospital das Clínicas, Faculty of Medicine, University of São Paulo - São Paulo/SP, Brazil. Bronchoscopy Unit, Pulmonary Division², Hospital das Clínicas, Faculty of Medicine, University of São Paulo - São Paulo/SP, Brazil.

E-mail: heloisa-carvalho@uol.com.br

Received for publication on February 24, 2005.

Accepted for publication on May 05, 2005. tages obtained with the use of HDR brachytherapy include good patient tolerance, short treatment time, and a higher potential to achieve local control.

The highly conformal nature of brachytherapy enables the radiation oncologist to accomplish safe escalation of radiation doses to the tumor while minimizing doses to normal surrounding structures. Most of the reported experience with endobronchial brachytherapy is related to treatment of primary or metastatic endobronchial lesions, either with curative or palliative intent. Very few articles report the use of brachytherapy for primary tracheal tumors. ${ }^{2-7}$ Due to the rarity of the disease $(0.2 \%-0.5 \%$ of all upper respiratory tract malignancies), ${ }^{8,9}$ the role of endoluminal brachytherapy in the treatment regimen of tracheal neoplasms has not been clearly defined yet.

Prognostic factors include performance status, weight loss, histological type, location in the trachea (upper, mid- 
Table 1 - Description of patient characteristics

\begin{tabular}{ccccccccc}
\hline Patient & Gender & Age & Histology & $\begin{array}{c}\text { DFS } \\
\text { (years) }\end{array}$ & $\begin{array}{c}\text { Tracheal } \\
\text { location }\end{array}$ & Ext. & $\begin{array}{c}\text { Obstr. } \\
\text { Score* }\end{array}$ \\
\hline 1 & M & 43 & SCC & - & Upper & $4 \mathrm{~cm}$ & 6 & N0 \\
2 & M & 78 & SCC & - & Lower & $3 \mathrm{~cm}$ & 2 & N0 \\
3 & F & 53 & ACC & 9 & Middle & $2.5 \mathrm{~cm}$ & 10 & N0 \\
4 & F & 61 & Plasm & 11 & Middle & $4 \mathrm{~cm}$ & 2 & N0 \\
\hline
\end{tabular}

*Obstruction Score (Speiser, $1993^{27}$ ): Tracheal obstruction $>50 \%=10 ;<50 \%=6$, and $<10 \%=2$.

$\mathrm{DFS}=$ disease free survival before first recurrence; Ext. = lesion extension; $\mathrm{LN}=$ lymph node involvement; $\mathrm{M}=$ male; $\mathrm{F}=$ female; $\mathrm{SCC}=$ squamous cell carcinoma; $\mathrm{ACC}=$ adenoid cystic carcinoma; Plasm = plasmacytoma

dle, or lower third), resectability, lymph node involvement, and surgical margins. ${ }^{10,11}$

Adenoid cystic carcinoma and squamous cell carcinoma are the most common tracheal tumors. Resection and postoperative radiation therapy are the treatment of choice. ${ }^{12,13}$ Complete resection is the desired goal, and benign tumors, for which cure can be expected, are best treated by resection alone.

We report the experience of a single institution with high dose-rate brachytherapy in the management of nonresected primary tracheal tumors.

\section{MATERIALSAND METHODS}

From 1991 to 1997, four patients with primary tracheal tumors were treated with endobronchial/endotracheal HDR brachytherapy: two men with squamous cell carcinoma, and two women, one with adenoid cystic carcinoma, one with primary tracheal plasmacytoma (previously published as a case report). ${ }^{14}$ Brachytherapy was indicated as a boost after external beam irradiation in 1 case of inoperable squamous carcinoma of the lower third of the trachea, which was asymptomatic at that time. The other patient with squamous cell carcinoma was previously irradiated for a head and neck tumor and received brachytherapy alone. He had an inoperable tumor located at the upper portion of the trachea, causing dyspnea, cough, and mild bleeding right below the supraclavicular radiation field limits. The 2 patients with adenoid cystic carcinoma and plasmacytoma, respectively, underwent brachytherapy as a salvage treatment for local recurrences after external beam irradiation years before ( 9 and 11 years, respectively). Diagnosis of recurrence was made after complaints of dyspnea and cough with mild bleeding in the first case and cough in the second one. Only the patient with plasmacytoma received laser therapy for debulking before irradiation. ${ }^{14}$ Table 1 presents patient characteristics, and Table 2 presents previous radiation treatments.
Endotracheal HDR brachytherapy was delivered in 3 or 4 fractions of 7.5 Gy each, at weekly intervals. Dose calculation was made at $1 \mathrm{~cm}$ from the source axis, with optimization on dose points. No centered catheters were available, and $6 \mathrm{Fr}$ catheters were used in all procedures. Nasal placement and fixation of the catheters with tape was used, except for the patient with previous larynx carcinoma, where the procedure was performed through the tracheotomy. One or two catheters were placed in the tracheal lumen and positioned in the right and/or left main bronchus, respectively. Proximal and distal margins of 1 to $2 \mathrm{~cm}$ from the lesion were included in the treatment volume, to account for possible variations due to respiratory cycles. Since there may be areas of very high radiation doses where the catheter surface is in contact with the airway mucosa, the volumes receiving the total dose (100\%), and those receiving $150 \%$ and $200 \%$ of the total dose were also evaluated (Table 3 ).

Follow-up was considered to start from the end of brachytherapy. The local response was evaluated by fiberbronchoscopy performed 30 to 40 days after the end of brachytherapy. Subsequent bronchoscopies were performed at 3 and 6 months after brachytherapy, and after that whenever indicated. Additionally, thoracic CT scans were performed every 6 months over the first 3 years, then yearly until at least 5 years of follow-up.

Table 2 - Previous external beam radiation treatment (patient \# 1 did not receive external beam irradiation)

\begin{tabular}{cccc}
\hline Patient & Total dose & Dose/fraction & Tracheal location \\
\hline 2 & $50 \mathrm{~Gy}$ & $2 \mathrm{~Gy}$ & Lower \\
3 & $* 60 \mathrm{~Gy}$ & $2 \mathrm{~Gy}$ & Middle \\
& $36 \mathrm{~Gy}$ & $1.8 \mathrm{~Gy}$ & Upper \\
4 & $* * 40 \mathrm{~Gy}$ & $2 \mathrm{~Gy}$ & Middle/lower \\
& $40 \mathrm{~Gy}$ & & Upper \\
\hline
\end{tabular}

*Two courses with $60 \mathrm{~Gy}$ and $36 \mathrm{~Gy}$, respectively, in adjacent fields, with a 6-month interval; ** Two courses of $40 \mathrm{~Gy}$, in adjacent fields, with a 5-year interval 
Table 3 - Brachytherapy characteristics

\begin{tabular}{|c|c|c|c|c|c|c|c|c|c|c|}
\hline Patient & $\begin{array}{c}\text { Total dose } \\
(\text { whole EBR + BT) }\end{array}$ & $\begin{array}{l}\text { BT total } \\
\text { dose }\end{array}$ & $\begin{array}{c}\text { BT } \\
\text { dose/fraction }\end{array}$ & $\begin{array}{l}\text { Interval between } \\
\text { fractions }\end{array}$ & $\begin{array}{l}\text { Number of } \\
\text { catheters }\end{array}$ & $\begin{array}{l}\mathrm{V} 100 \\
\left(\mathrm{~cm}^{3}\right)\end{array}$ & $\begin{array}{l}\mathrm{V} 150 \\
\left(\mathrm{~cm}^{3}\right)\end{array}$ & $\begin{array}{l}\mathrm{V} 200 \\
\left(\mathrm{~cm}^{3}\right)\end{array}$ & $\mathrm{V} 150 / \mathrm{V} 100$ & V200/V100 \\
\hline & & & $7.5 \mathrm{~Gy}$ & & 2 & 31.08 & 15.60 & 9.79 & 0.49 & 0.31 \\
\hline \multirow[t]{4}{*}{1} & $30 \mathrm{~Gy}$ & $30 \mathrm{~Gy}$ & $7.5 \mathrm{~Gy}$ & 2 weeks & 2 & 31.52 & 15.49 & 9.45 & 0.49 & 0.30 \\
\hline & & & 7.5 Gy & & 2 & 37.06 & 20.15 & 12.05 & 0.53 & 0.32 \\
\hline & & & 7.5 Gy & & 2 & 38.46 & 20.24 & 12.05 & 0.53 & 0.31 \\
\hline & & & $7.5 \mathrm{~Gy}$ & & 1 & 11.44 & 5.58 & 3.25 & 0.49 & 0.28 \\
\hline \multirow[t]{3}{*}{2} & $67.5 \mathrm{~Gy}$ & $17.5 \mathrm{~Gy}$ & $5.0 \mathrm{~Gy}$ & 1 week & 1 & 12.26 & 6.77 & 4.20 & 0.55 & 0.34 \\
\hline & & & $5.0 \mathrm{~Gy}$ & & 1 & 11.16 & 5.86 & 3.65 & 0.52 & 0.33 \\
\hline & & & $7.5 \mathrm{~Gy}$ & & 1 & 10.41 & 5.27 & 3.31 & 0.51 & 0.32 \\
\hline \multirow[t]{3}{*}{3} & $118.5 \mathrm{~Gy}$ & $22.5 \mathrm{~Gy}$ & $7.5 \mathrm{~Gy}$ & 1 week & 2 & 13.82 & 7.32 & 4.96 & 0.53 & 0.36 \\
\hline & & & $7.5 \mathrm{~Gy}$ & & 1 & 10.05 & 5.41 & 3.41 & 0.54 & 0.34 \\
\hline & & & $7.5 \mathrm{~Gy}$ & & 1 & 16.87 & 8.72 & 5.54 & 0.52 & 0.33 \\
\hline \multirow[t]{2}{*}{4} & $102.5 \mathrm{~Gy}$ & $22.5 \mathrm{~Gy}$ & $7.5 \mathrm{~Gy}$ & 1 week & 2 & 22.90 & 11.93 & 7.44 & 0.52 & 0.32 \\
\hline & & & 7.5 Gy & & 2 & 23.36 & 12.33 & 7.70 & 0.53 & 0.32 \\
\hline
\end{tabular}

EBR: external beam radiotherapy; BT: brachytherapy; V100: volume enclosed by the 100\% isodose curve; V150: volume enclosed by the $150 \%$ isodose curve; V200: volume enclosed by the $200 \%$ isodose curve

\section{RESULTS}

All patients presented complete local response at the time of first bronchoscopic evaluation, with improvement of related symptoms in 2 of the 3 symptomatic cases. No biopsy was performed in order to avoid the risk of fistulae or bleeding of the irradiated areas. The 2 patients with squamous cell carcinoma died at $6^{\text {th }}$ and $33^{\text {rd }}$ months after brachytherapy, respectively. The first, with no evidence of local disease and persistent cough, died of respiratory infection. No direct relationship with treatment was detected, but in the last bronchoscopic evaluation, 3 months after treatment, there was still moderate necrosis in the irradiated areas, perhaps facilitating an infection. The second patient, who received brachytherapy as a boost, died with local recurrence 2 years after treatment. Two patients were alive, with no evidence of disease at 64 and 110 months of follow-up. Tracheal stenosis was observed in these 2 patients-and was considered a severe complication-22 and 69 months after brachytherapy, respectively. Both had been extensively irradiated previously, with areas that received 60 to 90 Gy (Table 4). A tracheal stent was successfully placed for palliation in the patient with adenoid cystic carcinoma, but it was not necessary for the plasmacytoma patient. During this period, this patient presented other isolated lesions in the upper respiratory tract (larynx and oropharynx), and was successfully treated with external beam irradiation. Nine years after brachytherapy, she developed chronic lymphocytic leukemia.

No relationship of the brachytherapy irradiated volumes and complications was observed.
Table 4 - Results and survival after the end of brachytherapy

\begin{tabular}{|c|c|c|c|c|c|}
\hline Patient & $\begin{array}{l}\text { Survival } \\
\text { (months) }\end{array}$ & $\begin{array}{c}\text { DFS } \\
\text { (months) }\end{array}$ & $\begin{array}{c}\text { Cause of } \\
\text { death }\end{array}$ & $\begin{array}{l}\text { Local } \\
\text { recurrence }\end{array}$ & Sequelae \\
\hline 1 & 6 & 6 & $\begin{array}{l}\text { Respiratory } \\
\text { infection }\end{array}$ & No & No \\
\hline 2 & 33 & 24 & Tumor & Yes & No \\
\hline 3 & 64 & 64 & - & No & $\begin{array}{c}\text { Stenosis } \\
(22 \text { months })\end{array}$ \\
\hline 4 & 110 & 110 & - & No & $\begin{array}{l}\text { Stenosis } \\
(69 \text { months })\end{array}$ \\
\hline
\end{tabular}

DFS $=$ disease free survival

\section{DISCUSSION}

Treatment of primary tracheal tumors has been optimized over the years. At first, most patients were treated with endoscopic or surgical local excision followed by radiotherapy with orthovoltage or radon seed implantation. One-year survival was less than $25 \%{ }^{15-17}$ Advances in surgical techniques have made it possible to resect tracheal tumors that might have previously been considered unresectable. ${ }^{18,19}$ At present, surgery has become the primary treatment for tracheal tumors. ${ }^{13,20}$ Advances in radiation therapy have shown modest gains in the treatment of tracheal malignancies, either as definitive or as adjuvant treatment. ${ }^{11,13,20-24}$

Schneider ${ }^{13}$ reported in his series of 14 resected cases, a 5 -year survival of $35.7 \%$ for 6 patients who needed adjuvant irradiation.

Kanematsu ${ }^{20}$ also reported, in 16 patients with adenoid cystic carcinoma, a 5-and 10-year survival of $91 \%$ and $76 \%$, respectively, for patients with resected tumors versus a 5 -year 
survival of $40 \%$ when combined with radiation therapy.

Two Russian series ${ }^{25,26}$ of 48 patients with squamous cell carcinoma of the trachea and 16 cases of adenoid cystic carcinoma had 5-year survival rates of $40.9 \%$ and $55.9 \%$, respectively, for patients treated with combined surgery and radiotherapy.

Schraube et al. ${ }^{7}$ reported 5 patients treated with endobronchial HDR brachytherapy: 4 combined with external beam irradiation, and 1 as a salvage treatment after surgery. External beam doses ranged from 46 to 60 Gy. Endobronchial HDR brachytherapy was delivered in 5 fractions of 3 to $4 \mathrm{~Gy}$ each, twice a week, calculated at $1 \mathrm{~cm}$ from the source axis. They reported 4 of 5 complete responses, 2 of 3 deaths for recurrent or progressive disease, and 2 patients alive with no evidence of disease at $37^{\text {th }}$ and $68^{\text {th }}$ months of follow-up.

The same group published results some years later, with 7 cases treated with brachytherapy as a boost for residual tumor after external irradiation. Local control was obtained in 5 of 7 patients, and late toxicity occurred in 3 patients ( 2 stenosis and 1 hemorrhage). Three-year actuarial survival was $32 \%{ }^{3}$

In this series, all 4 patients achieved immediate complete response, with palliation of symptoms and local control for at least 6 months. Palliation was achieved mainly due to improvement of obstruction. This might also have been evaluated by pulmonary function tests, with determination of the maximum flows, and thereby detecting impairment of high airways. But, in the present study, these tests were not performed.

The patients with adenoid cystic carcinoma and plasmacytoma had a better outcome, as expected. These patients also presented with tracheal stenosis, and one of them was treated with local stent placement. They persisted with only mild limitations due to dyspnea. We considered the high doses of either external beam irradiation, with a partial dose overlap between fields, and endoluminal brachytherapy, to have been the main cause of stenosis. It is conceivable that more fractions with lower brachytherapy doses might have avoided or diminished this risk.

Nevertheless, Schraube ${ }^{7}$ also reported 2 of 5 tracheitis with stenosis in his series, and Harms ${ }^{3}$ reported 1 case of late hemorrhage using 4 or 5 fractions of brachytherapy with lower doses/fraction.

We observed that dose distribution using 2 catheters seemed to be better than using a single one. The $100 \%$ isodose curve may be widened to more than $2 \mathrm{~cm}$ diameter, allowing better coverage of tracheal walls, which was associated with a lower surface dose (Table 3). This strategy may be used to diminish the risk of complications, especially when centralized catheters are not available.

\section{CONCLUSIONS}

Endobronchial HDR brachytherapy may be used for tracheal tumors as a boost for external beam irradiation or in recurrences. Total dose and dose/fraction have not yet been well defined; however, 3 or 4 fractions of 5 to $7.5 \mathrm{~Gy}$ (at $1 \mathrm{~cm}$ depth) are currently used. Although survival impact was not demonstrated in this series, local control of 3 out of 4 patients indicates that individual cases may benefit from the treatment. Long-term survival with palliation may also be expected mainly in cases of adenoid cystic histology.

\section{RESUMO}

Carvalho H de A, Figueiredo V, Pedreira Jr. WL, Aisen S. Braquiterapia de alta taxa de dose como opção terapêutica nos tumores primários da traquéia. Clinics. 2005;60(4):299304.

OBJETIVO: Apresentar a experiência do tratamento de 4 pacientes com tumores primários de traquéia, não operados, submetidos à braquiterapia endobrônquica de alta taxa de dose.
PACIENTES E MÉTODOS: Dois casos de carcinoma espinocelular, uma recidiva de carcinoma adenóide cístico e uma recidiva de plasmocitoma primário da traquéia. Todos receberam braquiterapia endobrônquica, exclusiva ou como reforço de dose da radioterapia externa. Foram administradas 3 ou 4 frações de 7,5 Gy cada, calculados a $1 \mathrm{~cm}$ de profundidade. O seguimento foi considerado a partir do término da braquiterapia.

RESULTADOS: Em todos os casos houve resposta completa. 
Dois pacientes com carcinoma espinocelular evoluíram a óbito em 6 e 33 meses após a braquiterapia, o primeiro, sem evidência de doença e o outro por recidiva local, respectivamente. As outras 2 pacientes encontravam-se vivas após 64 e 110 meses de seguimento, sem evidência de doença. Esses 2 casos apresentaram estenose traqueal em 22 e 69 meses após a braquiterapia, sendo necessária a colocação de prótese traqueal apenas na paciente com carcinoma adenóide cístico.

CONCLUSÕES: A braquiterapia endobrônquica de alta taxa de dose pode ser utilizada tanto como reforço de dose da irradiação externa quanto em recidivas. O controle local obtido em 3 de 4 pacientes indica que casos individuais podem se beneficiar desse procedimento. Sobrevida a longo prazo pode ser observada, principalmente nos casos de histologia adenóide cística.

\section{UNITERMOS: Radioterapia. Braquiterapia. Tumores de traquéia. Alta taxa de dose. Complicações.}

\section{REFERENCES}

1. Aisen S, Carvalho HA, Chavantes MC, Esteves SCB, Haddad CMK, Pernomian AC, et al. Braquiterapia de alta taxa de dose. Rev Hosp Clín Fac Med S Paulo. 1992;47:121-4.

2. Aggarwal A, Tewari S, Mehta AC. Successful management of adenoid cystic carcinoma of the trachea by laser and irradiation. Chest. 1999;116:269-70.

3. Harms W, Latz D, Becker H, Herth F, Schraube P, Krempien R, Wannenmacher M. HDR-brachytherapy boost for residual tumour after external beam radiotherapy in patients with tracheal malignancies. Radiother Oncol. 1999;52:251-5.

4. Kohek PH, Pakisch B, Glanzer H. Intraluminal irradiation in the treatment of malignant airway obstruction. Eur J Surg Oncol. 1994;20:674-80.

5. Makarewicz R, Mross M. Radiation therapy alone in the treatment of tumors of the trachea. Lung Cancer. 1998;20:169-74.

6. Mornex F, Coquard R, Danhier S, Maingon P, Husseini GE, Houtte $\mathrm{PV}$. Role of radiation therapy in the treatment of primary tracheal carcinoma. Int J Radiat Oncol Biol Phys. 1998;41:299-305.

7. Schraube P, Latz D, Wannenmacher M. Treatment of primary squamous cell carcinoma of the trachea: the role of radiation therapy. Radiother Oncol. 1994;33:254-8.

8. Ampil FL. Primary malignant tracheal neoplasms: case reports and literature radiotherapy review. J Surg Oncol. 1986;33:20-3.

9. Houston HE, Payne WS, Harrison EG Jr, Olsen AM. Primary cancers of the trachea. Arch Surg. 1969;99:132-40.

10. Regnard JF, Fourquier P, Levasseur P. Results and prognostic factors in resections of primary tracheal tumors: a multicentric retrospective study. J Thorac Cardiovasc Surg. 1996;111:808-14.

11. Chao MWT, Smith JG, Laidlaw C, Joon DL, Ball D. Results of treating primary tumors of the trachea with radiotherapy. Int $\mathrm{J}$ Radiat Oncol Biol Phys. 1998;41:779-85.
12. Grillo HC, Mathisen DJ. Primary tracheal tumors: treatment and results. Ann Thorac Surg. 1990;49:69-77.

13. Schneider P, Schirren J, Muley T, Vogt-Moykopf I. Primary tracheal tumors: experience with 14 resected patients. Eur J Cardiothorac Surg. 2001;20:12-8.

14. Kairalla RA, Carvalho CRR, Parada AA, Alves VA, Saldiva PH. Solitary plasmacytoma of the trachea treated by loop resection and laser therapy. Thorax. 1988,43:1011-2.

15. Chow DC, Komaki R, Libshitz H, Mountain CF, Ellerbroek N. Treatment of primary neoplasms of the trachea: The role of radiation therapy. Cancer. 1993;71:2946-52.

16. Hajdú SI, Huvos AG, Goodner JT, Foote FW, Beattie EJ. Carcinoma of the trachea: clinicopathologic study of 41 cases. Cancer. 1970;25:1448-56.

17. McCafferty GJ, Parker LS, Suggit SC. Primary malignant disease of the trachea. J Laryngol. 1964;78:441-79.

18. Grillo HC, Dignan EF, Miura T. Extensive resection and reconstruction of mediastinal trachea without prosthesis or graft: an anatomical study in man. J Thorac Cardiovasc Surg. $1964 ; 48: 741$.

19. Grillo HC. Tracheal surgery. J Thorac Cardiovasc Surg.1983;17:6777.

20. Kanematsu T, Uehara T, Ushijima C, Asoh H, Yoshino I, Ichinose Y. Treatment outcome of resected and non-resected primary adenoid cystic carcinoma of the lung. Ann Thorac Cardiovasc Surg. 2002;8:74-7.

21. Baraka ME. Malignant tumors of the trachea. Ann R Coll Surg Engl. 1984;66:27-9.

22. Fields JN, Rigaud G, Emami BN. Primary tumors of the trachea: results of radiation therapy. Cancer. 1989;63:2429-33. 
23. Pearson FG, Todd TR Jr, Cooper JD. Experience with primary neoplasms of the trachea and carina. J Thorac Cardiovasc Surg. 1984;88:511-8.

24. Rostom AY, Morgan RL. Results of treating primary tumors of the trachea by irradiation. Thorax. 1978;33:387-93.

25. Kharchenko VP, Galil-Ogly GA, Gvarishvili AA, II'in VI, Al'bekov RZ. Lechenie plockokletochnogo raka trachei. [Treatment of squamous cell carcinoma of the trachea]. Vopr Onkol. 1999;45:66-9.
26. Kharchenko VP, Galil-Ogly GA, Gvarishvili AA, II'in VI, Al'bekov RZ. Luchevaia terapila adenokistoznogo raka trakhei. [Radiotherapy for cystadenoma of the trachea]. Vopr Onkol. 1999;45:69-72.

27. Speiser BL, Spratling L. Remote afterloading brachytherapy for the local control of endobronchial carcinoma. Int J Radiat Oncol Biol Phys. 1993;25:579-87. 